\title{
Paternity analysis in a litter of whale shark embryos
}

\author{
Jennifer V. Schmidt1,2,*, Chien-Chi Chen ${ }^{3}$, Saad I. Sheikh ${ }^{4,8}$, Mark G. Meekan ${ }^{5}$, \\ Bradley M. Norman ${ }^{6,7}$, Shoou-Jeng Joung ${ }^{3}$ \\ ${ }^{1}$ Department of Biological Sciences, University of Illinois at Chicago, 900 S. Ashland Avenue, MC 567, Chicago, \\ Illinois, 60607, USA \\ ${ }^{2}$ Shark Research Institute, PO Box 70, Princeton, New Jersey, 08540, USA \\ ${ }^{3}$ Department of Environmental Biology and Fisheries Science, National Taiwan Ocean University, 2 Pei-Ning Road, \\ Keelung, Taiwan 20224, Republic of China \\ ${ }^{4}$ Department of Computer Science, University of Illinois at Chicago, 851 S. Morgan Street, MC 152, Chicago, \\ Illinois, 60607, USA \\ ${ }^{5}$ Australian Institute of Marine Science, UWA Ocean Sciences Center (MO96), 35 Stirling Highway, Crawley, \\ Western Australia 6009, Australia \\ ${ }^{6}$ ECOCEAN Inc., 68A Railway Street, Cottesloe, Western Australia 6011, Australia \\ ${ }^{7}$ Centre for Fish \& Fisheries Research, Murdoch University, South Street, Murdoch, Western Australia 6150, Australia \\ ${ }^{8}$ Present address: Laboratoire d'Informatique (LIX), Ecole Polytechnique, Palaiseau CEDEX 91120, France
}

\begin{abstract}
A $10.6 \mathrm{~m}$ female whale shark Rhincodon typus caught off the coast of eastern Taiwan in 1995 carried 304 embryos that ranged in developmental stage from individuals still in egg cases to hatched and free-swimming near-term animals. This litter established that whale sharks develop by aplacental yolk-sac viviparity, with embryos hatching from eggs within the female. The range of developmental stages in this litter suggested ongoing fertilization over an extended period of time, with embryos of different ages possibly sired by different males. A series of 9 microsatellite markers for $R$. typus have now been used to investigate paternity in a subset of these embryos. We determined the paternity of 29 embryos representing $10 \%$ of the original litter, and spanning most of the range of size and developmental stage of the 304 embryos. All were full siblings sired by the same male, suggesting that this male may have sired the entire litter. Probability analysis indicates that a second male could go undetected if it sired less than $10 \%$ of the litter. The range of developmental stages of embryos from this single sire further suggests that female whale sharks may have the ability to store sperm for later fertilization. In the absence of any tissue to determine parental genotypes, maternal mitochondrial sequence was obtained from the embryos, identifying a novel haplotype linked to those from the western Indian Ocean. This finding adds further support for the global population structure emerging for $R$. typus.
\end{abstract}

KEY WORDS: Rhincodon typus $\cdot$ Whale shark $\cdot$ Genetics $\cdot$ Paternity $\cdot$ Microsatellite $\cdot$ Mitochondria

\section{INTRODUCTION}

The whale shark Rhincodon typus is the largest extant shark, reaching lengths of $18 \mathrm{~m}$ or more (Compagno 2001). Whale sharks frequent tropical and warm temperate waters globally, feeding on plankton, krill, and coral and fish spawn (Heyman et al. 2001, Jarman \& Wilson 2004, Graham \& Roberts 2007, Hoffmayer et al. 2007, Nelson \& Eckert 2007). A wide-ranging epipelagic species, whale sharks were virtually unstudied until the mid-1990s, when it was discovered that large numbers congregate at seasonal feeding aggregations in shallow coastal waters (Taylor 1996, Pravin 2000, Eckert \& Stewart 2001, Heyman et al. 2001, Hoffmayer et al. 2007, Jonahson \& Harding 2007, Rowat \& Gore 2007, Rowat et al. 2007). Since then, numerous behavioral, ecological and genetic studies have been published (for general reviews of whale shark biology see Colman 1997, Martin 2007, Stevens 2007). The current population status of $R$. typus is unknown, but it is be- 
lieved that numbers are declining in parts of its range. Whale sharks are listed as Vulnerable in the IUCN Red List of Threatened Species, and the species was placed on CITES Appendix II in 2002.

Despite the increasing amount of research directed towards understanding this species, whale sharks remain a biological enigma. Virtually nothing is known about their breeding and reproduction, for example, and whale shark mating has never been observed. It is not known where whale sharks are born, and very young whale sharks are almost never found. Only 12 sub-1 m animals have been recorded in the scientific literature (Wolfson 1983, Rowat et al. 2008). The feeding aggregations where most whale shark research is conducted are composed primarily of juvenile males; adult female whale sharks have been reported in significant numbers only in the Sea of Cortez, the Galapagos Islands and the Philippines (Ramirez-Macias et al. 2007, M. Levine unpubl. data, E. Aca unpubl. data). Given this apparent segregation by sex and age, it is unclear if whale shark mating occurs in pairs or in larger groups, as seen in some shark species (Carrier et al. 1994, Whitney et al. 2004).

Whale sharks were long thought to be oviparous, based on a single egg case from the Gulf of Mexico that carried a live $37 \mathrm{~cm}$ total length (TL) embryo (Baughman 1955, Compagno 2001). It was only in 1995 that the first pregnant female whale shark was found; a $10.6 \mathrm{~m}$ TL female caught in Taiwan carried 304 embryos in her uteri (Joung et al. 1996, Leu et al. 1997). Analysis of 237 of these embryos showed a remarkable distribution of size and developmental stage, ranging from animals as small as $42 \mathrm{~cm}$ TL retained in egg cases, to hatched animals up to $64 \mathrm{~cm}$ TL free-living in the uterus (Joung et al. 1996, Chang et al. 1997, Leu et al. 1997). This single female established that whale shark reproduction is aplacental viviparous (ovoviviparous): females give birth to live young that hatch internally. The largest hatched embryos from the Taiwan female were viable outside the uterus, and 2 were kept in aquaria for more than 4 mo (Chang et al. 1997). Two additional Rhincodon typus females have been reported from waters off China, one pregnant with 16 embryos and one gravid with 200 eggs (Compagno 2001). Unfortunately, no additional information is available for these animals. Fifteen years later, the animal caught in Taiwanese waters remains the only documented evidence of reproductive mode and embryonic development in whale sharks.

Genetic analysis provides a means to examine reproductive behavior when direct observation is not possible. In particular, monoandrous versus polyandrous mating strategies can be investigated by genetic analysis of the offspring of individual females, with the qualifier that any one monoandrous litter cannot definitively rule out polyandry in other litters (Sugg \& Chesser 1994). Using a panel of polymorphic genetic markers, the presence of no more than 4 parental alleles per locus is suggestive of monogamy within the litter, while the presence of more than 4 parental alleles indicates polyandry. Only a few species of shark have been analyzed with respect to paternity, with the finding of varying degrees of polyandry (Table 1). Bonnethead sharks Sphyrna tiburo, for example, have largely single-sire litters, while lemon sharks Negaprion brevirostris may give birth to litters with as many as 5 different sires (Chapman et al. 2004, Feldheim et al. 2004). It seemed plausible that the Taiwan whale shark embryos of varying developmental age might have been sired by different males during separate mating events.

Though most of the embryos recovered from the Taiwan female were discarded, 29 embryos that had been

Table 1. Genetic analysis of paternity in sharks. n/a: not available

\begin{tabular}{|c|c|c|c|c|}
\hline Species & Common name & $\begin{array}{l}\text { Litters with multiple } \\
\text { paternity/total litters }\end{array}$ & $\begin{array}{l}\text { Sires } \\
\text { per litter }\end{array}$ & Source \\
\hline Ginglymostoma cirratum & Nurse shark & $1 / 1$ & $\geq 4$ & Saville et al. (2002) \\
\hline Squalus acanthias & Spiny dogfish & $3 / 10$ & 2 & Lage et al. (2008) \\
\hline Squalus mitsukurii & Shortspine spurdog & $3 / 27$ & $\geq 2$ & Daly-Engel et al. (2010) \\
\hline Carcharhinus altimus & Bignose shark & $1 / 1$ & $\geq 2$ & Daly-Engel et al. (2006) \\
\hline Carcharhinus galapagensis & Galapagos shark & $0 / 1$ & $\mathrm{n} / \mathrm{a}$ & Daly-Engel et al. (2006) \\
\hline \multirow[t]{3}{*}{ Carcharhinus plumbeus } & Sandbar shark & $17 / 20$ & $2-5$ & Portnoy et al. (2007) \\
\hline & & $8 / 20$ & $\geq 2$ & Daly-Engel et al. (2007) \\
\hline & & $1 / 1$ & $\geq 2$ & Daly-Engel et al. (2006) \\
\hline \multirow[t]{2}{*}{ Negaprion brevirostris } & Lemon shark & $1 / 1$ & $\geq 3$ & Feldheim et al. (2001) \\
\hline & & $86 \%$ of litters ${ }^{\mathrm{a}}$ & $\mathrm{n} / \mathrm{a}$ & Feldheim et al. (2004) \\
\hline Sphyrna tiburo & Bonnethead shark & $4 / 22^{\mathrm{b}}$ & $\geq 2$ & Chapman et al. (2004) \\
\hline
\end{tabular}


frozen since their recovery have now been analyzed to evaluate single or multiple paternity. To estimate the number of sires for this litter, embryos were genotyped at 9 microsatellite loci. Several possible outcomes of this analysis can be predicted. The embryos might have been sired by multiple males, with paternity segregating with developmental stage, which would suggest mating events with different males at different times. Alternatively, there might be multiple paternity, yet no correlation with developmental stage. In this case, the female may have mated with different males in a short time, with the developmental staging a result of sperm storage with later fertilization or embryonic diapause. Genetic analysis might instead reveal evidence for only a single sire for all embryos. Such a result for 1 litter cannot establish monogamy for the species, but would provide strong evidence for sperm storage and delayed fertilization.

\section{MATERIALS AND METHODS}

Morphological observation and tissue harvest. The Taiwan whale shark embryos were collected in 1995, when Rhincodon typus was legally fished in Taiwan, and before current species protections were in place. Prior to the present study the embryos had been frozen at $-20^{\circ} \mathrm{C}$ for $14 \mathrm{yr}$ and stored in the Joung laboratory at the National Taiwan Ocean University in Keelung, Taiwan. For the present analysis, the embryos were thawed at room temperature, measured, photographed, and tissue samples harvested. The animals were not weighed, because freezing had caused liquefaction of internal tissues. Sex was determined by the presence of claspers on males, which are apparent even at embryonic stages (see Fig. S1 in Supplement 1 at www.int-res.com/articles/suppl/n012p117_supp.pdf). Deep muscle from the ventral surface at the base of the tail showed good preservation, and $1 \times 3 \mathrm{~cm}$ sections of tissue were removed from each animal into 100\% ethanol. Fresh scalpel blades were used for each embryo to minimize the possibility of DNA cross-contamination between embryos.

DNA preparation and genotyping. Genomic DNA was prepared from $50 \mathrm{mg}$ embryo tissue using the DNeasy kit (Qiagen) and quantified on a nanodrop spectrophotometer (Thermo Scientific). DNAs were stored at $-80^{\circ} \mathrm{C}$, with working aliquots stored at $-20^{\circ} \mathrm{C}$. Approximately $40 \mathrm{ng}$ of DNA was amplified using fluorescently labeled primers for 9 microsatellite loci. These included 7 loci published previously by our group (Rtyp1-5 and Rtyp7-8; Schmidt et al. 2009), 1 locus published by another group (Rty38; RamirezMacias et al. 2009) and 1 locus not yet formally published (Rtyp9, previously known as D112; Meekan et al. 2008). Rtyp1-5 and Rtyp7-8 were amplified as described previously (Schmidt et al. 2009). The Rty38 locus was amplified using the primers Rty38ForF, 5'CGG GTC TAC AGC AGG TGA AT-3' and Rty38RevT, 5'-GAC TCC AGA CCC ACA GCA AT-3', with the cycling parameters $94^{\circ} \mathrm{C}$ for $20 \mathrm{~s}, 57^{\circ} \mathrm{C}$ for $20 \mathrm{~s}, 72^{\circ} \mathrm{C}$ for 20 s, 35 cycles. The Rtyp9 locus was amplified using the primers Rtyp9ForF, 5'-AGG TCC CTT CTC TCT TGA AAG G-3', and Rtyp9RevT, 5'-GTG TCT TAC AGC AAT TCG CAG TTC TTT TGG-3', with the cycling parameters $94^{\circ} \mathrm{C}$ for $40 \mathrm{~s}, 54^{\circ} \mathrm{C}$ for $40 \mathrm{~s}, 72^{\circ} \mathrm{C}$ for 40 s, 35 cycles. PCR reactions for Rty38 and Rtyp9 were performed in $20 \mu \mathrm{l}$ volumes with the following mix: 50 $\mathrm{mM} \mathrm{KCl}, 10 \mathrm{mM}$ Tris- $\mathrm{HCl}, 1.5 \mathrm{mM} \mathrm{MgCl}, 200 \mu \mathrm{M}$ of each dNTP, $50 \mu \mathrm{M}$ of each primer and $0.1 \mathrm{U}$ AmpliTaq Gold DNA polymerase (Applied Biosystems). All reactions incorporated the GeneScan 350 ROX internal size standard (Applied Biosystems). PCR products were resolved on a 3730 DNA Analyzer, and data managed using GeneMapper software (Applied Biosystems). All animals were analyzed in duplicate at each locus (i.e. amplified, electrophoresed and independently scored a second time), and in each run animals analyzed in our previous population study were incorporated as controls (Schmidt et al. 2009).

Genetic analysis. Microsatellite data for Rtyp9 was evaluated for the presence of null alleles, stuttering and small allele dominance using MICRO-CHECKER Version 2.2.3 (Van Oosterhout et al. 2004). Locus statistics and concordance with Hardy-Weinberg equilibrium were calculated using FSTAT (Goudet 1995). Genotype data were assayed for sibling relationships using COLONY Version 2.0, which implements a maximum likelihood method to assign sibship among individuals using multi-locus genotypes (Wang 2004, Wang \& Santure 2009). COLONY was run with the default parameters, set for medium run, full-likelihood analysis, assuming polygamy for males and females without parental genotype data. The program KINALYZER was also used to reconstruct relationships (kinalyzer.cs.uic.edu). KINALYZER uses combinatorial optimization based on the rules of Mendelian inheritance to reconstruct sibling groups, and is specifically designed for analyses where parental genotypes are not available (Berger-Wolf et al. 2007, Ashley et al. 2009). Two independent KINALYZER algorithms were compared: the 2-allele minimum set cover determined the smallest number of sibling groups that could contain all individuals, while consensus-based error-tolerant reconstruction used the default parameters to compare sibling groups derived from subsets of loci. PrDM (Probability of Detecting Multiple Matings) was run to estimate the power of the 9 microsatellite loci to identify multiple sires, if present, under varying degrees of paternal skew (Neff \& Pitcher 2002). Probability of 
identity was calculated using CERVUS 3.0.3 (Marshall et al. 1998, Kalinowski et al. 2007).

Mitochondrial control region amplification and sequencing. The Rhincodon typus mitochondrial control region was amplified by PCR from embryo genomic DNA as described in Castro et al. (2007). Amplification was performed with primers WSCR1F and WSCR1R under conditions of $50 \mathrm{mM} \mathrm{KCl}, 10 \mathrm{mM}$ Tris$\mathrm{HCl}_{1} 1.5 \mathrm{mM} \mathrm{MgCl}_{2}, 200 \mu \mathrm{M}$ of each dNTP, $50 \mu \mathrm{M}$ of each primer, and $0.25 \mathrm{U}$ Taq DNA polymerase (Sigma), with a program of $94^{\circ} \mathrm{C}$ for $2 \mathrm{~min}, 54^{\circ} \mathrm{C}$ for $2 \mathrm{~min}, 72^{\circ} \mathrm{C}$ for 2 min, 35 cycles. Fragments were analyzed on $1 \%$ agarose gels, cloned with the TopoTA cloning kit (Invitrogen) and sequenced using SP6 and T7 vector primers and the WSCR2R primer. To distinguish between sequence polymorphisms and introduced Taq errors, 4 different embryos were individually amplified, cloned, sequenced and aligned. This comparison revealed only a single base pair difference among the 4 animals, which reamplification and direct sequencing revealed to be a low frequency Taq-induced mutation. The Taiwan control region sequence was aligned to known $R$. typus mitochondrial haplotypes using Vector NTI (Invitrogen) (Castro et al. 2007).

\section{RESULTS}

\section{Morphological characteristics of the whale shark embryos}

The 29 whale shark embryos analyzed genetically spanned nearly the full range of sexes, sizes and developmental stages of the embryos that were initially studied from the Taiwan litter (Joung et al. 1996, Chang et al. 1997). The original embryo size profile ranged from 42 to $64 \mathrm{~cm} \mathrm{TL}$, and the animals were grouped into 3 classes: Class 1, 42-52 cm TL; Class 2, 52-58 $\mathrm{cm} \mathrm{TL}_{;}$and Class 3,58-64 cm TL. The 29 remaining embryos spanned a size range of 48 to $61 \mathrm{~cm}$ (Table S1 in Supplement 1 at www.int-res. com/articles/suppl/n012p117_supp.pdf), with 8 embryos from Class 1, 15 from Class 2, and 6 from Class 3 , and contained 15 male and 14 female animals. Despite the long period of storage, the embryos were externally intact and in relatively good condition (Fig. S2 in Supplement 1 at www.int-res.com/articles/ suppl/n012p117_supp.pdf). Left gill region spot pattern photos were submitted to the ECOCEAN Whale Shark Photo-ID Database (www.whaleshark. org) (Arzoumanian et al. 2005). Based on the dissection of 2 specimens, internal tissue preservation was poor, precluding any analysis of internal anatomy. Morphological differences corresponded to size and developmental stage; larger animals had a more elongated body shape, with the pectoral fins curved more posteriorly (Fig. S2 in Supplement 1). Small but definitive claspers were clearly evident on male embryos, allowing determination of sex (Fig. S1 in Supplement 1).

\section{Characterization of additional microsatellite loci}

Analysis of the Rhincodon typus embryos provided additional data for the microsatellite loci we characterized previously (Schmidt et al. 2009). A new Rtyp3 allele (240) was found that represents a missing step in the dinucleotide series, and one Rtyp8 allele that was present in only a single animal in the global study must have been present in one of the parents of this litter (Table S2 in Supplement 1 at www.intres.com/articles/suppl/n012p117_supp.pdf). Previous characterization of the Rty38 locus identified 5 alleles among 50 animals from Holbox Island, Mexico (Ramirez-Macias et al. 2009). In the present study, analysis across a panel of 26 globally distributed whale sharks identified 6 alleles for Rty38, though it is not possible to compare these across platforms with the Holbox alleles (data not shown). The Rtyp9 locus is a (TAGA) repeat for which population analysis has not previously been reported. Amplification of this locus across 32 globally distributed whale sharks identified 21 alleles (data not shown). The Rtyp9 locus was evaluated with MICRO-CHECKER Version 2.2.3 with a confidence interval of $99 \%$, and showed no evidence for scoring error, large allele dropout or null alleles (Van Oosterhout et al. 2004). FSTAT was used to calculate observed $\left(H_{0}=0.954\right)$ and expected heterozygosity $\left(H_{\mathrm{e}}=0.944\right)$ and FIS $\left(F_{\mathrm{IS}}=0.038\right)$ for Rtyp9, indicating no deviation from Hardy-Weinberg equilibrium (Goudet 1995).

\section{Genetic inference of parentage}

None of the 9 microsatellite loci showed the presence of more than 4 alleles in the whale shark embryo population, strongly suggesting that a single male sired all 29 embryos (Table S2 in Supplement 1). For all loci, allele segregation conformed well to expected Mendelian ratios. Parental genotypes were reconstructed for each locus, although with no parental tissue available, maternal and paternal genotypes could not be distinguished. Three different methods were used for sibling reconstruction. COLONY analysis assigned all embryos to a single full sibling group with pairwise probabilities of 0.998 to 1.00 , and an overall probability of 0.998 (Wang 2004, Wang \& Santure 2009). Maximum likelihood estimates showed the best family configuration to be a single sire. KINALYZER 
analysis using 2 different algorithms (2-allele set cover and consensus) also reconstructed a single full sibling group (Berger-Wolf et al. 2007, Ashley et al. 2009). Therefore, all 29 embryos were almost certainly sired by the same male, and this data suggests the entire litter may be full siblings as well. An alternate possibility, that 2 or more males with the same genotype sired the embryos, is unlikely, as the probability of identity for the 9 microsatellite loci employed in this analysis is $1.3 \times 10^{-9}$.

It remains possible, however, that the embryo subset analyzed might not include embryos sired by a second male if paternal mating success was highly skewed. The ability of our analysis to detect a minor contribution by a second sire was calculated using the program PrDM (Neff \& Pitcher 2002). PrDM uses the number of microsatellite loci analyzed, the number of alleles at each locus and their frequencies within the population under study to calculate the likelihood that all offspring are full siblings for given levels of paternal skew. Estimating a hypothetical paternal skew of 95:5 (one sire responsible for $95 \%$ of the embryos and another responsible for 5\%) yields a PrDM value of 0.769. Estimating a paternal skew of 90:10 yields a PrDM value of 0.95 ; smaller degrees of skew generate increasingly more significant values. Repeated runs of each simulation gave nearly identical results. These data show that our analysis has the power to determine with statistical significance a minor sire that represents $10 \%$ or more of the litter.

\section{Identification of maternal mitochondrial haplotype}

No tissue was available to determine parental genotypes, but it is possible to obtain some maternal genetic information from the maternally inherited mitochondrial DNA of the offspring. The Taiwan female mitochondrial haplotype has a control region of 1222 base pairs that is most similar to the previously described H41 and H44 Rhincodon typus haplotypes. This haplotype differs from $\mathrm{H} 41$ by a single $\mathrm{T}$ to $\mathrm{C}$ transition at position 995, and from H44 by a 17 base pair indel at position 815 and a $\mathrm{T}$ to $\mathrm{C}$ transition at position 1012. This new haplotype has been designated H45, and submitted to GenBank under the accession number GU289922.

\section{DISCUSSION}

\section{The whale shark embryos derive from a single sire}

The varying developmental stages of the whale shark embryos suggested the possibility of multiple sires, yet genetic analysis has shown that the 29 em- bryos are full siblings sired by a single male. This conclusion is supported by multiple analytic approaches at high probability, and suggests that the entire litter was derived from the same male. While it cannot be ruled out that additional males sired embryos among those that were discarded, PrDM analysis shows that the microsatellite analysis employed here could discriminate a second sire if his offspring comprised $10 \%$ or more of the litter. A second possibility, that 2 or more males with identical genotypes sired the embryos, is very unlikely; probability of identity calculation shows that this panel of microsatellite markers can differentiate individuals among a theoretical population of 1 billion whale sharks.

Paternity has been examined in 8 species of shark (Table 1), with some degree of polyandry found in 7 of these. The contribution of multiple sires varies widely across species, from $86 \%$ multiple paternity in lemon sharks to only $11 \%$ in the shortspine spurdog Squalus mitsukurii (Feldheim et al. 2004, Daly-Engel et al. 2010). Some sharks practice group mating, where multiple paternity likely results from repeated inseminations during a single mating event (Carrier et al. 1994, Whitney et al. 2004). Polyandry can afford substantial benefits for animals, particularly in species where pairs stay together from courtship through raising young. Sharks meet only briefly to mate, however, with no evidence for pair bonding or parental care after birth. The wide range of multiple paternity, along with the fact that even highly polyandrous species do not show multiple paternity in all litters, makes it impossible to extrapolate from 1 whale shark litter to Rhincodon typus as a species. Should a value of $<10 \%$ be borne out, however, this would be a low level of polyandry in comparison to most shark species examined to date (Table 1).

\section{Continuous fertilization suggests sperm storage}

Variation in the size of offspring within a litter is common in sharks, but typically all embryos are at equivalent developmental stages. In some species, this variation is due to differences in size of the ova at fertilization (Braccini et al. 2007). Variation in developmental stage is more unusual, and could result from differences in timing of fertilization or possibly from embryonic diapause. It has been suggested that such staggered development is a characteristic of species capable of long-term sperm storage with ongoing fertilization (Pratt 1993). Female whale sharks may therefore be able to store sperm after a single mating, and then fertilize eggs over an extended period of time, such that a developmental continuum is seen. 
Sharks store sperm in the oviducal or shell gland, a region of the oviduct responsible for formation of the egg capsule. Blue shark Prionace glauca females may carry embryos in markedly different stages of development, and pregnant blue sharks have been found with sperm in the oviducal gland, suggesting sperm storage longer than their gestation period of 9 to 12 mo (Pratt 1979, Hazin et al. 1994). Sperm storage with delayed fertilization also occurs in the whitespotted bamboo shark Chiloscyllium plagiosum between mating in December-January and ovulation in March-May, and in the tiger shark Galeocerdo cuvier between mating in January-February and ovulation in May-July (Chen \& Liu 2006, Whitney \& Crow 2007). Pratt (1993) suggests that in certain species the oviducal tubules may be morphologically specialized to act as sperm storage receptacles (Hamlett et al. 1993). Analysis of the whale shark oviducal gland may reveal adaptations for long-term sperm storage.

It cannot be entirely ruled out that the staggered development of the whale shark embryos is a result of diapause, a prolonged period of developmental stasis prior to implantation. Diapause has been described in at least 3 species of sharks and rays, which have been found with early embryos dormant in the uterus (Snelson et al. 1989, Simpfendorfer 1992, White et al. 2002). In species with diapause, however, the embryos typically implant en masse, and development ensues in a coordinated manner. The production of embryos along a developmental continuum as seen in the whale shark, assuming only a single mating and/or fertilization, would require varying lengths of diapause for different groups of embryos. To our knowledge such a process has not been demonstrated in any elasmobranch.

\section{The Taiwan female identifies a new mitochondrial haplotype}

Sequencing of the whale shark embryo mitochondrial control region identified a previously unreported maternal haplotype designated H45. This haplotype is most closely related to the haplotypes H41 and H44, both found in single animals from the western Indian Ocean (Castro et al. 2007). Finding a close variant to haplotypes identified far from Taiwan waters provides additional support for the low population differentiation seen among whale sharks using both mitochondrial and nuclear markers (Castro et al. 2007, Schmidt et al. 2009). The home territories and migratory patterns of adult female whale sharks are unknown; the lack of haplotype geographic segregation suggests that females may travel across oceans to breed.

\section{Implications for biology and conservation}

While it is impossible to extrapolate the data from any single litter to the species as a whole, the results presented here allow for some speculation on the breeding habits of whale sharks. Much data on Rhincodon typus reproduction is lacking; female habitat and the existence of breeding grounds (if any) or pupping grounds (if any) are all unknown. Genetic analysis using nuclear and mitochondrial markers indicates a single, worldwide whale shark breeding population, yet whale sharks segregate by sex and size. This suggests that the species may have a breeding ground(s) where adults congregate. It has been proposed that in some species multiple paternity is a function of population density and sex ratio on mating grounds (DalyEngel et al. 2010). A higher degree of polyandry would then suggest that common mating grounds may exist, while monoandry would reflect more isolated mating events between individual animals. The finding of little or no polyandry in this whale shark litter, should it prove to be typical for the species, argues against the existence of specific mating areas. Identifying the habitat of adult whale sharks, particularly adult females, will be necessary to answer this question.

The determination of polyandry versus monoandry has implications for the genetic health of a species. It has been suggested (e.g. Yasui 1998), somewhat controversially, that polyandry increases genetic diversity within a population. Practical tests of this theory have not borne out a genetic benefit, however, and it may be that such benefits are specific to certain species or reproductive strategies (Feldheim et al. 2004, DiBattista et al. 2008). Polyandry functions to increase effective population size, which indirectly increases genetic diversity through a greater number of successfully reproducing males (Daly-Engel et al. 2010). Such an effect would provide a hedge against loss of diversity and mating depression in declining species, of which Rhincodon typus may be one (Bradshaw et al. 2008).

The 304 embryos in the Taiwan whale shark litter represent a remarkable number of offspring for a single female, the highest ever recorded for a shark. If typical of the species, such high fecundity may serve to buffer a high predation rate for Rhincodon typus newborns. Pupping areas would likely be visited by large numbers of predators, and neonatal whale sharks have been found in the stomachs of blue sharks and blue marlin Makaira mazara (Kukuyev 1996, Rowat et al. 2008). Large litter sizes would offset high predation in general, while staggered delivery would result in smaller numbers of animals being born at different times and perhaps in different areas. If pupping areas and/or juvenile nurseries do not exist for $R$. typus, this strategy would reduce the risk of loss of an entire litter in any one location. 
Acknowledgements. The authors thank M. Ashley (University of Illinois at Chicago) and K. Feldheim (Field Museum of Natural History) for a critical reading of the manuscript, S. Planes (University of Perpignan) for the use of the Rtyp9 microsatellite locus, T. Ronan (University of Illinois at Chicago) for statistical advice, and 3 anonymous reviewers for comments on the manuscript. Microsatellite analysis was performed in the Field Museum of Chicago's Pritzker Laboratory for Molecular Systematics and Evolution, operated with support from the Pritzker Foundation. This work was funded by a grant from Project Aware (to J.V.S.).

\section{LITERATURE CITED}

Arzoumanian Z, Holmberg J, Norman B (2005) An astronomical pattern-matching algorithm for computer-aided identification of whale sharks Rhincodon typus. J Appl Ecol 42:999-1011

Ashley MV, Caballero IC, Chaovalitwongse W, Dasgupta B, Govindan P, Sheikh SI, Berger-Wolf TY (2009) KINALYZER, a computer program for reconstructing sibling groups. Mol Ecol Resour 9:1127-1131

> Baughman JL (1955) The oviparity of the whale shark, Rhineodon typus, with records of this and other fishes in Texas waters. Copeia 1955:54-55

$>$ Berger-Wolf TY, Sheikh SI, DasGupta B, Ashley MV, Caballero IC, Chaovalitwongse W, Putrevu SL (2007) Reconstructing sibling relationships in wild populations. Bioinformatics 23:I49-I56

> Braccini JM, Hamlett WC, Gillanders BM, Walker TI (2007) Embryo development and maternal-embryo nutritional relationships of piked spurdog (Squalus megalops). Mar Biol 150:727-737

Bradshaw CJA, Fitzpatrick BM, Steinberg CC, Brook BW Meekan MG (2008) Decline in whale shark size and abundance at Ningaloo reef over the past decade: the world's largest fish is getting smaller. Biol Conserv 141: 1894-1905

> Carrier JC, Pratt HL, Martin LK (1994) Group reproductive behaviors in free-living nurse sharks, Ginglymostoma cirratum. Copeia 646-656

> Castro ALF, Stewart BS, Wilson SG, Hueter RE, and others (2007) Population genetic structure of earth's largest fish, the whale shark (Rhincodon typus). Mol Ecol 16: $5183-5192$

> Chang WB, Leu MY, Fang LS (1997) Embryos of the whale shark, Rhincodon typus: early growth and size distribution. Copeia 1997:444-446

Chapman DD, Prodohl PA, Gelsleichter J, Manire CA, Shivji MS (2004) Predominance of genetic monogamy by females in a hammerhead shark, Sphyrna tiburo: implications for shark conservation. Mol Ecol 13:1965-1974

Chen WK, Liu KM (2006) Reproductive biology of whitespotted bamboo shark Chiloscyllium plagiosum in northern waters off Taiwan. Fish Sci 72:1215-1224

Colman JG (1997) A review of the biology and ecology of the whale shark. J Fish Biol 51:1219-1234

Compagno L (2001) Sharks of the world: an annotated and illustrated catalogue of shark species known to date. Bullhead, mackerel and carpet sharks (Heterodontiformes, Lamniformes, and Orectolobiformes), Vol 2. Food and Agriculture Organization of the United Nations, Rome

> Daly-Engel TS, Grubbs RD, Holland KN, Toonen RJ, Bowen BW (2006) Assessment of multiple paternity in single litters from three species of carcharhinid sharks in Hawaii. Environ Biol Fishes 76:419-424
Daly-Engel T, Grubbs R, Bowen B, Toonen R (2007) Frequency of multiple paternity in an unexploited tropical population of sandbar sharks, Carcharhinus plumbeus. Can J Fish Aquat Sci 64:198-204

$>$ Daly-Engel TS, Grubbs RD, Feldheim KA, Bowen BW, Toonen RJ (2010) Is multiple mating beneficial or unavoidable? Low multiple paternity and genetic diversity in the shortspine spurdog Squalus mitsukurii. Mar Ecol Prog Ser 403:255-267

DiBattista JD, Feldheim KA, Gruber SH, Hendry AP (2008) Are indirect genetic benefits associated with polyandry? Testing predictions in a natural population of lemon sharks. Mol Ecol 17:783-795

Eckert SA, Stewart BS (2001) Telemetry and satellite tracking of whale sharks, Rhincodon typus, in the Sea of Cortez, Mexico, and the north Pacific Ocean. Environ Biol Fishes 60:299-308

Feldheim KA, Gruber SH, Ashley MV (2001) Multiple paternity of a lemon shark litter (Chondrichthyes: Carcharhinidae). Copeia 781-786

Feldheim KA, Gruber SH, Ashley MV (2004) Reconstruction of parental microsatellite genotypes reveals female polyandry and philopatry in the lemon shark, Negaprion brevirostris. Evolution 58:2332-2342

Goudet J (1995) FSTAT (Version 1.2): a computer program to calculate F-statistics. J Hered 86:485-486

Graham RT, Roberts CM (2007) Assessing the size, growth rate and structure of a seasonal population of whale sharks (Rhincodon typus Smith 1828) using conventional tagging and photo identification. Fish Res 84:71-80

Hamlett WC, Eulitt AM, Jarrell RL, Kelly MA (1993) Uterogestation and placentation in elasmobranchs. J Exp Zool 266:347-367

Hazin FHV, Kihara $\mathrm{K}$, Otsuka $\mathrm{K}$, Boeckman CE, Leal EC (1994) Reproduction of the blue shark Prionace glauca in the south-western equatorial Atlantic Ocean. Fish Sci 60: 487-491

> Heyman WD, Graham RT, Kjerfve B, Johannes RE (2001) Whale sharks Rhincodon typus aggregate to feed on fish spawn in Belize. Mar Ecol Prog Ser 215:275-282

Hoffmayer ER, Franks JS, Driggers WB III, Oswald KJ, Quattro JM (2007) Observations of a feeding aggregation of whale sharks, Rhincodon typus, in the north central Gulf of Mexico. Gulf Caribb Res 19:69-73

Jarman SN, Wilson SG (2004) DNA-based species identification of krill consumed by whale sharks. J Fish Biol 65: 586-591

Jonahson M, Harding S (2007) Occurrence of whale sharks (Rhincodon typus) in Madagascar. Fish Res 84:132-135

Joung SJ, Chen CT, Clark E, Uchida S, Huang WYP (1996) The whale shark, Rhincodon typus, is a livebearer: 300 embryos found in one 'megamamma' supreme. Environ Biol Fishes 46:219-223

Kalinowski ST, Taper ML, Marshall TC (2007) Revising how the computer program CERVUS accommodates genotyping error increases success in paternity assignment. Mol Ecol 16:1099-1106

Kukuyev E (1996) The new finds in recently born individuals of the whale shark Rhiniodon typus (Rhiniodontidae) in the Atlantic Ocean. J Ichthyol 36:203-205

> Lage C, Petersen C, Forest D, Barnes D, Kornfield D, Wray C (2008) Evidence of multiple paternity in spiny dogfish (Squalus acanthias). J Fish Biol 73:2068-2074

Leu M, Chang W, Fang L (1997) The success of keeping a baby whale shark from its fetal stage in Taiwan. Proceedings of the Fourth International Aquarium Congress, Tokyo (23-27 June 1996), p 109-111 
Marshall TC, Slate J, Kruuk LE, Pemberton JM (1998) Statistical confidence for likelihood-based paternity inference in natural populations. Mol Ecol 7:639-655

Martin RA (2007) A review of behavioural ecology of whale sharks (Rhincodon typus). Fish Res 84:10-16

Meekan MG, Speed CW, Planes S, McLean C, Bradshaw CJA (2008) Population monitoring for whale sharks (Rhincodon typus). Report prepared for the Australian Government Department of the Environment, Water, Heritage and the Arts. Australian Institute of Marine Science, Townsville, QLD

Neff BD, Pitcher TE (2002) Assessing the statistical power of genetic analyses to detect multiple mating in fishes. J Fish Biol 61:739-750

Nelson JD, Eckert SA (2007) Foraging ecology of whale sharks (Rhincodon typus) within Bahia de Los Angeles, Baja California Norte, Mexico. Fish Res 84:47-64

Portnoy DS, Piercy AN, Musick JA, Burgess GH, Graves JE (2007) Genetic polyandry and sexual conflict in the sandbar shark, Carcharhinus plumbeus, in the western north Atlantic and Gulf of Mexico. Mol Ecol 16:187-197

Pratt HL (1979) Reproduction in the blue shark, Prionace glauca. Fish Bull 77:445-470

$>$ Pratt HL (1993) The storage of spermatozoa in the oviducal glands of western north-Atlantic sharks. Environ Biol Fishes 38:139-149

Pravin P (2000) Whale shark in the Indian coast - need for conservation. Curr Sci 79:310-315

> Ramirez-Macias D, Vazquez-Juarez R, Galvan-Magana F, Munguia-Vega A (2007) Variations of the mitochondrial control region sequence in whale sharks (Rhincodon typus) from the Gulf of California, Mexico. Fish Res 84 $87-95$

Ramirez-Macias D, Shaw K, Ward R, Galvan-Magana F, Vazquez-Juarez R (2009) Isolation and characterization of microsatellite loci in the whale shark (Rhincodon typus). Mol Ecol Resour 9:798-800

Rowat D, Gore M (2007) Regional scale horizontal and local scale vertical movements of whale sharks, in the Indian Ocean off Seychelles. Fish Res 84:32-40

Rowat D, Meekan MG, Engelhardt U, Pardigon B, Vely M (2007) Aggregations of juvenile whale sharks (Rhincodon typus) in the Gulf of Tadjoura, Djibouti. Environ Biol Fishes 80:465-472

Rowat D, Gore MA, Baloch BB, Islam Z, and others (2008) New records of neonatal and juvenile whale sharks (Rhin-

Editorial responsibility: Brendan Godley,

University of Exeter, Cornwall Campus, UK codon typus) from the Indian Ocean. Environ Biol Fishes 82:215-219

Saville K, Lindley A, Maries E, Carrier J, Pratt H (2002) Multiple paternity in the nurse shark, Ginglymostoma cirratum. Environ Biol Fishes 63:347-351

Schmidt JV, Schmidt CL, Ozer F, Ernst RE, Feldheim KA, Ashley MV, Levine M (2009) Low genetic differentiation across three major ocean populations of the whale shark, Rhincodon typus. PLoS ONE 4:e4988

Simpfendorfer CA (1992) Reproductive strategy of the Australian sharpnose shark, Rhizoprionodon taylori (Elasmobranchii, Carcharhinidae), from Cleveland Bay, northern Queensland. Aust J Mar Freshw Res 43:67-75

Snelson FF, Williamshooper SE, Schmid TH (1989) Biology of the bluntnose stingray, Dasyatis sayi, in Florida coastal lagoons. Bull Mar Sci 45:15-25

Stevens JD (2007) Whale shark (Rhincodon typus) biology and ecology: a review of the primary literature. Fish Res 84:4-9

Sugg DW, Chesser RK (1994) Effective population sizes with multiple paternity. Genetics 137:1147-1155

Taylor JG (1996) Seasonal occurrence, distribution and movements of the whale shark, Rhincodon typus, at Ningaloo reef, Western Australia. Mar Freshw Res 47:637-642

Van Oosterhout C, Hutchinson W, Wills D, Shipley P (2004) MICRO-CHECKER: software for identifying and correcting genotyping errors in microsatellite data. Mol Ecol Notes 4:535-538

Wang J (2004) Sibship reconstruction from genetic data with typing errors. Genetics 166:1963-1979

Wang J, Santure AW (2009) Parentage and sibship inference from multilocus genotype data under polygamy. Genetics 181:1579-1594

White WT, Hall NG, Potter IC (2002) Reproductive biology and growth during pre- and postnatal life of Trygonoptera personata and T. mucosa (Batoidea: Urolophidae). Mar Biol 140:699-712

Whitney NM, Crow GL (2007) Reproductive biology of the tiger shark (Galeocerdo cuvier) in Hawaii. Mar Biol 151:63-70

- Whitney NM, Pratt HL, Carrier JC (2004) Group courtship, mating behaviour and siphon sac function in the whitetip reef shark, Triaenodon obesus. Anim Behav 68:1435-1442

Wolfson FH (1983) Records of 7 juveniles of the whale shark, Rhiniodon typus. J Fish Biol 22:647-655

Yasui Y (1998) The 'genetic benefits' of female multiple mating reconsidered. Trends Ecol Evol 13:246-250

Submitted: November 24, 2009; Accepted: June 17, 2010

Proofs received from author(s): June 20, 2010 